\title{
CAT Gene
}

National Cancer Institute

\section{Source}

National Cancer Institute. CAT Gene. NCI Thesaurus. Code C61060.

This gene plays a role in both the catabolism of reactive oxygen species and detoxification of hydrogen peroxide. 